J. Dairy Sci. 96:6539-6549

http://dx.doi.org/10.3168/jds.2012-6489

(C) American Dairy Science Association ${ }^{\circledR}, 2013$.

\title{
The effect of increasing the nutrient and amino acid concentration of milk diets on dairy heifer individual feed intake, growth, development, and lactation performance
}

\author{
J. K. Margerison, ${ }^{* 1}$ A. D. J. Robarts, $†$ and G. W. Reynolds $\ddagger$ \\ *Institute of Agriculture and Environment, College of Sciences, Massey University, Private Bag 11222, Palmerston North 4442, New Zealand \\ †JMR Ltd., Farm Advisory Services, Palmerston North 4410, New Zealand \\ fInstitute of Food Nutrition and Human Health, College of Health, Massey University, Private Bag 11222, Palmerston North 4442, New Zealand
}

\begin{abstract}
Increasing early $(<3$ mo) nutrient feeding levels and growth rate of dairy calves has been found to increase their milk production potential. The objective of this study was to compare the effect of offering milk diets with or without added carbohydrates and amino acids on calf growth, weaning age, and subsequent growth and milk yield of dairy heifers in their first lactation. Friesian calves born at Massey University $(\mathrm{n}=57)$ were selected at random, weighed, and allocated to receive 1 of 3 diets. All calves were fed colostrum from 1 to $3 \mathrm{~d}$ of age, followed by $4 \mathrm{~L}$ of whole milk (WM) per head per day and probiotics between 3 and $18 \mathrm{~d}$ of age. At $18 \mathrm{~d}$ of age, calves were weighed to ensure mean body weight (BW); then, at $19 \mathrm{~d}$ of age, calves changed diets to 1 of 3 treatments, which reached full treatment rate at $21 \mathrm{~d}$ of age. The diets were $4 \mathrm{~L} /$ head per day of WM (M); 4 L/head per day of WM plus $200 \mathrm{~g}$ of plant carbohydrates (MP); and $4 \mathrm{~L} /$ head per day of WM plus $200 \mathrm{~g}$ of plant carbohydrates with amino acids (MPA). Calves were weaned upon reaching a BW of $90 \mathrm{~kg}$. During this period, BW, body condition, and hip height and width were measured. The heifers were commingled and grazed on ryegrass and white clover pastures until calving at 23 mo of age, when BW, body condition, and hip height and width were measured again. Milk yield and composition were measured throughout first lactation. At weaning, calves fed MPA had greater mean BW gain, a lower number of days to target $\mathrm{BW}$, and a greater mean hip width gain compared with calves in the M group, although mean gain in hip height did not differ among treatments. Total calf starter intake during the milk period was lower for MPA-fed calves compared with those offered $\mathrm{M}$, mainly due to a shorter milk feeding period required
\end{abstract}

Received December 16, 2012.

Accepted April 28, 2013.

${ }^{1}$ Corresponding author: j.margerison@massey.ac.nz to attain the $90-\mathrm{kg}$ weaning weight, whereas mean daily starter intake and straw intake did not differ. No difference was observed in the calving rate or calving age of heifers in any of the dietary feeding groups. First lactation fat-corrected milk yield, milk fat percentage, and total milk fat and protein yields were greater for animals reared on MP and MPA compared with M. Body weight, hip height and width at parturition, milk protein percentage, somatic cell count, or days in milk did not differ among treatments. Increasing nutrient intake, during the milk feeding period, improved the BW gain of calves and milk production of dairy heifers during first lactation.

Key words: calf, nutrition, milk yield

\section{INTRODUCTION}

Recent research on dairy heifer nutrition has shown that feeding greater amounts and feeding milk for longer periods benefits calf growth rates and subsequent heifer performance. Studies have also shown that increasing energy and protein intake during the milk-feeding period increases calf growth rate and first lactation milk yield (Khan et al., 2011; Bach, 2012; Soberon et al., 2012).

Increasing whole milk (WM) and milk replacer (MR) feeding levels has been found to decrease starter feed intake (Jasper and Weary, 2002; Margerison and Downey, 2005) and retard rumen development and growth at weaning (Suarez-Mena et al., 2011). A relationship has been clearly demonstrated between milk feeding and starter intake (Terré et al., 2007; Raeth-Knight et al., 2009). The intake of calf starter feeds is greater when milk-feeding levels are restricted, typically equivalent to $10 \%$ of BW (Margerison and Downey, 2005; Khan et al., 2007 a,b), and shows a sharp increase when milk was withdrawn completely (Jasper and Weary, 2002). Whereas increasing milk-feeding volume was found to reduce starter intake at weaning to half that of calves offered milk at the equivalent to $10 \%$ of BW (Jasper and Weary, 2002; Cowles et al., 2006; Raeth-Knight 
et al., 2009), which, more importantly, would result in BW loss and difficulty for the calf following weaning.

Higher growth rates in dairy calves are typically achieved by increasing MR (Bartlett et al., 2006; Davis Rincker et al., 2011; Soberon et al., 2012) or WM feeding levels from 10 to $17.9 \%$ (Jasper and Weary, 2002) and up to $20 \%$ of BW (Khan et al., 2007a, 2011). Furthermore, dairy calves fed increasing amounts of MR, from 562 to $1,358 \mathrm{~g} / \mathrm{d}$ (Cowles et al., 2006) and 423 to 704 $\mathrm{g} / \mathrm{d}$ (Bascom et al., 2007), were found to benefit from MR that had greater CP concentrations (up to $31 \%$ of DM) with less gross energy (4.9 to $5.2 \mathrm{kcal} / \mathrm{g}$ ) derived from fat (fat $=15$ to $21 \%$ of DM; Cowles et al., 2006; Bascom et al., 2007). Such changes in the composition of MR have achieved greater growth rates and energy retention, along with lower fat and greater lean tissue deposition (Diaz et al., 2001; Tikofsky et al., 2001). In these studies, maintaining the energy concentration of MR was achieved by the addition of carbohydrates from milk (lactose $=42.9$ to $43.4 \%$ of DM; Diaz et al., 2001; Tikofsky et al., 2001; Hill et al., 2010). In older calves, between 2 to 13 wk of age, lactose can be replaced by cereals (Huber et al., 1968; Toullec, 1989) as a nonfat energy source due to the development of pancreatic function (Guilloteau et al., 2009).

In New Zealand, the majority of dairy calves are fed colostrum, followed by WM from cows that produce milk with a relatively high fat-to-protein ratio $(\mathbf{F}: \mathbf{P})$ of 1.26:1 (New Zealand Dairy Statistics, 2012). Studies in which calves were offered milk diets with greater F:P ratios in WM (1.37:1) and MR (1:22:1) had body fat deposition levels greater than calves offered MR with lower F:P ratios (between 0.56 and 1.00; Bascom et al., 2007). This highlights the problems associated with high-F:P-WM diets and the potential benefits of reducing energy intake from fat or increasing the nonfat energy and protein concentration of WM diets. Recent research elucidated the specific AA deposited in the tissues in growing calves (Van Amburgh, 2012); increasing the concentrations of a selection of AA was shown to promote growth rates in growing calves fed MR (Hill et al., 2007). Yet, WM can be low in some AA, particularly Thr and Met plus Cys (Toullec, 1989). The hypothesis tested in the current study was whether increasing nonfat energy and the specific AA concentration of WM diets would achieve greater calf growth rates while avoiding starter intake depression, and would this affect the first lactation milk yield. The nonfat energy and protein concentration supplied in WM diets could potentially be increased by the addition of cereal carbohydrates and proteins; would the addition of these along with specific AA, known to be required by young calves, further increase growth rates or milk yields? The aim of this research was to add plant carbohydrates and proteins, with and without specific AA, to a WM (and compare this with WM fed at restricted levels) and measure the effect of these diets on the growth rate, feed intake, and height of young calves, and to assess the effect of these diets on the weight, height, and lactation performance of first lactation dairy heifers.

\section{MATERIALS AND METHODS}

\section{Animals}

The experimental design of this study and all associated procedures were approved by the Massey University Animal Ethics Committee. Included in this study were 57 Holstein Friesian heifer calves born at Massey University Dairy Unit \#1, Palmerston North, New Zealand, between August and October 2007.

Newborn calves were collected from the calving paddock (twice daily) and fed $3 \mathrm{~L} / \mathrm{d}$ of first-day milking colostrum, with a minimum of $50 \mathrm{~g} / \mathrm{L}$ of IgG, offered within the first 12 to $16 \mathrm{~h}$ of birth (split over 2 feedings), and then 3.5 to $4 \mathrm{~L} /$ head per day of first -day milking fresh colostrum for the following $2 \mathrm{~d}$ (split over 2 feedings in the morning and evening). Calves were weighed (BW $>34 \mathrm{~kg}$ for all calves) and housed in individual pens $(1.2 \times 2.0 \mathrm{~m})$ that were bedded on a sand base with the addition of sawdust, which was replenished daily. Calves had the umbilicus treated with a $7 \%$ iodine solution, and blood samples were collected from the jugular vein $24 \mathrm{~h}$ after the first feeding of colostrum. Samples were then analyzed for total serum protein levels (Reichert AR 200 digital hand-held refract meter; Reichert Inc., Depew, NY) and IgG concentration (by radial immune diffusion; VMRD Inc., Pullman, WA). At $4 \mathrm{~d}$ of age, colostrum was replaced by WM with probiotics (X Factor, Bell-Booth Ltd., Palmerston North, New Zealand) offered in the morning and evening $(2 \mathrm{~L}$ of WM plus $25 \mathrm{~g}$ of probiotic was offered twice daily, equivalent to $4 \mathrm{~L}$ with $50 \mathrm{~g}$ of probiotic/head day). The milk was retail quality $(3.51 \pm 0.25 \%$ protein, 4.42 $\pm 0.24 \%$ fat, $4.2 \pm 0.06 \%$ lactose, and SCC of $157 \pm$ $42.6 \times 10^{3}$ per $\mathrm{mL}$ ), and was offered at approximately $28^{\circ} \mathrm{C}$ using plastic calf feeding containers (4-L capacity; Stallion Plastics Ltd., Palmerston North, New Zealand) fitted with rubber nipples.

\section{Dietary Treatments}

At $18 \mathrm{~d}$ of age, calves were weighed and assigned to 1 of 3 milk treatments, according to BW, birth date, and breeding worth for milk production, which were continued until weaning at $90 \mathrm{~kg}$ of BW. The treatment groups were $4 \mathrm{~L} /$ head per day of WM with nothing 
added $(\mathbf{M}) ; 4 \mathrm{~L} /$ head per day of WM with an additional $200 \mathrm{~g}$ of plant carbohydrates (MP); and $4 \mathrm{~L} /$ head per day of WM with an additional $200 \mathrm{~g}$ of plant carbohydrates plus AA (MPA). The MPA diet had synthetic AA added to ensure that the overall Met, Lys, and Thr intake met requirements described by Hill et al. (2008), namely $0.037 \mathrm{~g}$ of Lys per gram of BW gain, a Met-to-Lys ratio of 0.31, a Met + Cys-to-Lys ratio of 0.54 , and a Thr-to-Lys ratio less than 0.60. The plant carbohydrate and proteins were a combination of low-amylose starches sourced from maize, barley, rice, and sorghum that were combined together with the complex carbohydrates present in Ascophylum nodosum. These were selected to ensure an amylose-toamylopectin ratio of $<10 \%$, and had been assessed and were found to increase calf growth when included in WM diets previously (J. K. Margerison, G. Reynolds, R. A. Laven, and A. D. J. Robarts, Massey University, unpublished data). The MP and MPA diets had a 200 $\mathrm{g} /$ head per day addition of the plant carbohydrates, and MPA had the additional AA added (Table 1; 2 different Queen of Calves formulations, Bell-Booth, Ltd., Palmerston North, New Zealand). In preparing the treatments, the MP and MPA diets were mixed with $1 \mathrm{~L}$ of $\mathrm{WM}$ and then had a further $3 \mathrm{~L}$ of $\mathrm{WM}$ added, which was mixed until fully combined. This was initially introduced to the calves at $19 \mathrm{~d}$ of age at 100 $\mathrm{g}$ /head per day for $2 \mathrm{~d}$ before increasing the rate to 200 $\mathrm{g} /$ head per day at $21 \mathrm{~d}$ of age.

The calves were fed $2 \mathrm{~L}$ of the WM twice daily (at 0730 and $1600 \mathrm{~h}$ ) until the introduction of the dietary treatments at $19 \mathrm{~d}$ of age. Thereafter, the 3 treatment groups were fed $4 \mathrm{~L}$ of WM once daily (at $0730 \mathrm{~h}$ ) until being abruptly weaned. The milk-feeding equipment was rinsed with cold water, washed, and disinfected with hot water plus a $5 \%$ hypochloride solution fol- lowing each feeding. All calves had ad libitum (with at least $10 \%$ refusal) access to a pelleted calf starter $(20 \%$ CP; Table 1) from $3 \mathrm{~d}$ of age (NRM Ltd., Auckland, New Zealand), barley straw (4-8 cm long) offered from hay nets, and fresh clean water from plastic buckets (mean preweaning intake $=3.0 \pm 0.31 \mathrm{~L} /$ head per day); all feeds were suspended above ground level in each pen and replenished twice daily. Calves were given local anesthetic before being dehorned at $5 \pm 0.5 \mathrm{wk}$ of age using a gas-powered hot disbudding iron, and vaccinated (Ultravac, Zoetis, Pfizer Animal Health NZ Ltd, Auckland, New Zealand) for a range of clostridia infections.

Calves were observed twice daily for any sign of illness (nasal discharge, cough, and diarrhea), and fecal consistency was scored using a 5 -point scale $(0=$ poor, runny to $5=$ very good, firm). During the milk feeding and early postweaning period, starter feed consumption and straw intake was measured in 2 consecutive days each week. Body weight, heart girth, withers height, hip height, and hip width were measured weekly.

\section{Post-Treatment Management}

Seven days after weaning calves from all treatments were comingled, turned out to pasture, and fed $\sim 2 \mathrm{~kg}$ of fresh matter/head per day of starter meal (16\% CP; NRM Ltd.; Table 1) for 4 wk. During this period, BW, hip height, and last rib girth were measured weekly. Heifers were grazed as a single group on the same pasture consisting predominantly of perennial rye grass (Lolium perenne L.) and white clover (Trifolium repens), with $<20 \%$ weeds and weed grasses (Poa annua), with a pregrazing mass of $3,079 \pm 648 \mathrm{~mm}$ and a postgrazing residual between $1,601 \pm 598$ and $1,798 \pm 561 \mathrm{~mm}$. Heifers continued to be grazed in a single group on pas-

Table 1. Mean $( \pm \mathrm{SE})$ chemical composition of feed consumed by calves between 3 and 12 wk of age

\begin{tabular}{|c|c|c|c|c|c|c|}
\hline $\begin{array}{l}\text { Composition, } \% \\
\text { (unless otherwise noted) }\end{array}$ & Carbohydrates & $\begin{array}{c}\text { Carbohydrates } \\
\text { with AA }\end{array}$ & $\begin{array}{l}20 \% \mathrm{CP}^{1} \\
\text { starter }^{1}\end{array}$ & Straw & $\begin{array}{l}16 \% \mathrm{CP}^{1} \\
\text { starter }^{1}\end{array}$ & Pasture \\
\hline DM & $89.0(0.12)$ & $89.0(0.12)$ & $89.5(0.62)$ & $87.4(3.10)$ & $89.5(0.63)$ & $20.0(0.13)$ \\
\hline Gross energy, KJ/g & $15.0(0.02)$ & $15.0(0.02)$ & $18.0(0.02)$ & $17.0(0.02)$ & $18.0(0.02)$ & $55.4(0.55)$ \\
\hline NDF & $1.1(0.09)$ & $1.1(0.09)$ & $18.6(1.31)$ & $80.4(2.86)$ & $18.9(1.34)$ & $43.0(0.15)$ \\
\hline $\mathrm{ADF}$ & $0.2(0.02)$ & $0.2(0.02)$ & $10.0(0.35)$ & $34.8(1.59)$ & $10.1(0.33)$ & $29.5(0.13)$ \\
\hline Ash & $1.0(0.01)$ & $1.0(0.01)$ & $7.7(0.41)$ & $9.1(1.10)$ & $7.8(0.43)$ & $8.0(0.07)$ \\
\hline Phosphorus & $1.6(0.11)$ & $1.6(0.10)$ & $0.68(0.01)$ & $0.09(0.02)$ & $0.68(0.02)$ & $0.25(0.01)$ \\
\hline $\mathrm{TDN}^{2}$ & - & - & 72.5 & 47.5 & 72.1 & 69.5 \\
\hline
\end{tabular}

${ }^{1}$ Pelleted calf starters contained wheat, wheat by-products, barley, barley by-products, maize, maize by-products, copra, palm kernel meal, oats, molasses, vegetable oil, fishmeal, milk powder, other protein sources, NPN, soybeans, peas, canola, sorghum, lucerne-grass meal, cottonseed meal, rice by-products, limestone, salt, dicalcium phosphate, sodium bentonite, coccidiostat, vitamins and minerals (NRM Ltd., Auckland, New Zealand).

${ }^{2}$ Total digestible nutrients were calculated using the equation given in NRC (2001). 
Table 2. Mean $( \pm \mathrm{SE})$ chemical composition of pasture offered to dairy heifers during the heifer growth period between 3 to 22 mo of age

\begin{tabular}{lcccc}
\hline & \multicolumn{4}{c}{ Age, mo } \\
\cline { 2 - 5 } Item & 3 to 5 & 5 to 10 & 10 to 15 & 15 to 22 \\
\hline DM, kg/animal per day & $4.7(0.45)$ & $6.0(0.59)$ & $7.8(0.81)$ & $10.5(1.0)$ \\
Composition, \% of DM & $20.0(0.13)$ & $19.5(0.12)$ & $20.5(0.12)$ & $20.4(0.11)$ \\
DM & $20.1(0.15)$ & $19.8(0.14)$ & $20.2(0.12)$ & $20.1(0.15)$ \\
CP & $41.5(0.13)$ & $42.3(0.13)$ & $43.0(0.14)$ & $42.1(0.14)$ \\
NDF & $28.5(0.13)$ & $29.0(0.12)$ & $29.0(0.11)$ & $28.5(0.12)$ \\
ADF & $7.9(0.06)$ & $8.0(0.07)$ & $8.1(0.06)$ & $8.0(0.07)$ \\
Ash & $2.4(0.01)$ & $2.5(0.01)$ & $2.3(0.01)$ & $2.6(0.01)$ \\
Fat & $2.8(0.15)$ & $2.9(0.15)$ & $2.6(0.15)$ & $2.6(0.15)$ \\
Sugar & $0.53(0.021)$ & $0.55(0.020)$ & $0.54(0.020)$ & $0.54(0.021)$ \\
Calcium & $0.26(0.010)$ & $0.27(0.021)$ & $0.25(0.010)$ & $0.25(0.011)$ \\
Phosphorus & 69.4 & 69.7 & 68.7 & 69.5 \\
TDN & &
\end{tabular}

${ }^{1}$ Dry matter offered and consumed was estimated on a weekly basis using feed offered and remaining, including paddock size and pasture height before and following grazing (residual pasture).

${ }^{2}$ Calculated using the equation given in NRC (2001).

tures of perennial rye grass and white clover with $<20 \%$ weed species and were offered a pasture mass between $3,199 \pm 654$ and $3,181 \pm 453 \mathrm{~kg} /$ ha with postgrazing residuals of $1,909 \pm 643$ to $1,598 \pm 627 \mathrm{~mm}$, equivalent to 4.0 and increasing to $8.0 \mathrm{~kg}$ of $\mathrm{DM} / \mathrm{head}$ per day (Table 2). Heifers were monitored at monthly intervals for BW until parturition during this time.

Heifers were mated naturally at $14 \pm 0.21$ mo of age; approximately 1 mo before calving heifers were transferred to Massey University Dairy Unit \#4, where they continued to be grazed together until calving at $23 \pm$ $0.24 \mathrm{mo}$ of age. Heifers grazed pastures of perennial rye grass and white clover with $<22 \%$ of weed species, with a weekly pasture mass between $3,102 \pm 645$ and 2,989 $\pm 436 \mathrm{~kg} / \mathrm{ha}$ and postgrazing residuals of $1,609 \pm 543$ to $1,502 \pm 427 \mathrm{~mm}$, equivalent to 9 and increasing to $11.5 \mathrm{~kg}$ of DM/head per day (Table 2). In the first $90 \mathrm{~d}$ postpartum, heifers grazed pasture and were offered 3 $\mathrm{kg}$ of maize silage each day and $2.0 \mathrm{~kg}$ of fresh matter/ head per day of dairy concentrate (Table 3 ). From calving to drying off, individual BW and milk yield were recorded daily, and milk composition and hip height and width were monitored weekly. All heifers were artificially inseminated at $50 \pm 0.72 \mathrm{DIM}$, after which they were served naturally from $95 \pm 0.72$ DIM onwards for a period of $28 \pm 0.72 \mathrm{~d}$. The number of inseminations for each animal was recorded and pregnancy rate was calculated from the percentage of heifers that were found to be pregnant, according to rectal palpation, 6 wk following removal of the bulls.

\section{Milk and Feed Composition}

Feed Analysis. Feed samples were collected weekly, bulked into monthly composite samples and sent to the
Massey University Feed Analysis Laboratory (Palmerston North, New Zealand) for determination of DM, $\mathrm{CP}, \mathrm{ADF}$, calcium, phosphorus (AOAC International, 2000), and NDF (Van Soest et al., 1991). Total digestible nutrients were calculated using the NRC (2001) equations. The chemical composition of starter, straw, and pasture provided to heifers over the experimental period are presented in Tables 1, 2 and 3.

Milk Samples and Analysis. During lactation, milk yield was recorded daily and milk samples were collected using in-line flow meters (DeLaval Ltd., Tumba, Sweden) on a weekly basis on 2 consecutive days (evening milking on the first day, morning milking on the second day). The milk flow was used to assess milk volume, and a $20-\mathrm{mL}$ sample, preserved with 1 potassium dichromate tablet, was used for the measurement of milk protein, fat, and SCC levels, using Fossomatic near-infrared technology (Livestock Improvement Co., Hamilton, New Zealand).

\section{Statistical Analysis}

Serum protein, IgG levels, fecal consistency, number of days animals required medication, starter and total DMI (hay plus starter), BW, BW gain, hip height, hip width, heart girth, and milk yield data were analyzed using a repeated-measures PROC MIXED model (SAS Institute, 2004) and were found to be normally distributed. The model included animal as the random component and serum protein, IgG levels, fecal consistency, number of days animals required medication, starter and total DMI (hay plus starter), BW, BW gain, hip height, hip width, heart girth, and milk yield data and diet, age, and their interactions as fixed components. The lowest Bayesian information criterion fit statistic 
Table 3. Mean $( \pm \mathrm{SE})$ chemical composition of feed to dairy heifers during the first lactation between 0 to 220 DIM

\begin{tabular}{|c|c|c|c|c|c|}
\hline \multirow[b]{2}{*}{ Item } & \multirow{2}{*}{$\begin{array}{c}\text { Dairy } \\
\text { concentrate }^{1}\end{array}$} & \multirow{2}{*}{$\begin{array}{l}\text { Maize } \\
\text { silage }^{2}\end{array}$} & \multicolumn{3}{|c|}{ Pasture quality by DIM } \\
\hline & & & 0 to $80 \mathrm{~d}$ & 80 to $160 \mathrm{~d}$ & 160 to $220 \mathrm{~d}$ \\
\hline $\mathrm{DM}, \mathrm{kg} /$ animal per day ${ }^{3}$ & & $3.0(0.29)$ & $15.0(1.41)$ & $18.0(1.72)$ & $18.1(1.83)$ \\
\hline \multicolumn{6}{|l|}{ Composition, $\%$ of DM } \\
\hline $\mathrm{DM}^{\mathrm{T}}$ & $89.5(0.62)$ & $30.1(0.32)$ & $20.5(0.11)$ & $20.9(0.12)$ & $20.0(0.11)$ \\
\hline $\mathrm{CP}$ & $18.3(0.21)$ & $7.8(0.61)$ & $20.1(0.13)$ & $21.5(0.15)$ & $20.1(0.14)$ \\
\hline $\mathrm{NDF}$ & $18.7(1.34)$ & $39.3(0.41)$ & $42.1(0.14)$ & $41.0(0.11)$ & $42.1(0.13)$ \\
\hline $\mathrm{ADF}$ & $10.1(0.37)$ & $24.1(0.20)$ & $28.5(0.12)$ & $27.5(0.11)$ & $28.0(0.12)$ \\
\hline Ash & $7.8(0.44)$ & $4.5(3.9)$ & $8.0(0.07)$ & $7.9(0.06)$ & $8.0(0.06)$ \\
\hline Fat & $7.0(0.35)$ & $4.1(0.39)$ & $2.6(0.01)$ & $2.7(0.01)$ & $2.6(0.02)$ \\
\hline Sugar & $4.5(0.28)$ & $3.4(0.41)$ & $2.6(0.15)$ & $2.9(0.14)$ & $2.6(0.13)$ \\
\hline Calcium & $1.23(0.030)$ & $0.26(0.23)$ & $0.54(0.020)$ & $0.55(0.020)$ & $0.54(0.01)$ \\
\hline Phosphorus & $0.68(0.010)$ & $0.25(0.22)$ & $0.25(0.010)$ & $0.26(0.010)$ & $0.25(0.02)$ \\
\hline $\mathrm{TDN}^{4}$ & 71.5 & 65.6 & 66.5 & 67.8 & 65.6 \\
\hline
\end{tabular}

${ }^{1}$ Dairy concentrate contained wheat, wheat by-products, barley, barley by-products, maize, maize by-products, copra, palm kernel meal, oats, molasses, vegetable oil, NPN, soybeans, peas, canola, sorghum, lucerne-grass meal, cottonseed meal, rice by-products, limestone, salt, dicalcium phosphate, sodium bentonite, vitamins and minerals (Denver Stock Feeds Ltd., Palmerston North, New Zealand).

${ }^{2}$ Soluble carbohydrates $=47 \%$.

${ }^{3}$ Dry matter offered was estimated on a weekly basis using feed offered and remaining, paddock size, and pasture height before and following grazing.

${ }^{4}$ Calculated using the equation given in NRC (2001).

level was used to select a covariance structure of a model for BW, hip height, hip width, and heart girth, but this was not required to be applied, as no significant difference was observed in BW, hip height, hip width, or heart girth of calves in each treatment group on diet allocation and at birth. Starter intake, total DMI, and BW gain of calves were analyzed in separate time periods between 1 to 18,19 to 39,40 to 60 , and 61 to $82 \mathrm{~d}$ of age, and also for the entire treatment period (19-82 d of age). Milk yield, milk composition, hip height and width, BW, BCS, and DIM were analyzed in the first lactation. Differences of fixed factors in the PROC MIXED model were evaluated across treatments by Tukey test. Reproduction data was analyzed as discrete data using Chi-squared. Statistical significance between treatment diets were established as $P<0.05$, and a tendency as $P<0.10$.

\section{RESULTS}

\section{Milk Feeding Period}

Health. No treatment differences were observed in serum protein, IgG levels, fecal consistency, or the number of days animals required medication (Table 4). These data indicate that the 3 treatment groups started at a similar base level of health and well-being and maintained it throughout the milk-feeding period.

Growth and Height. The number of days taken to achieve the target weaning BW $(\sim 90 \pm 0.59 \mathrm{~kg})$ was lower in calves receiving MPA compared with those receiving $\mathrm{M}$. Calves fed the MP diet did not differ from calves fed M (Table 4). The mean ADG was greater over the treatment-feeding period $(19 \mathrm{~d}$ to weaning) for calves fed MPA compared with those fed M (Table 5), whereas MP and M did not differ. Interestingly, the difference between groups was greatest between $61 \mathrm{~d}$ and weaning. In addition, over the treatment feeding period, a difference in mean hip width and heart and last rib girth gain was observed between calves offered MPA and calves offered M, whereas MP ADG and hip width mean gain did not differ from MPA or M.

Feed Intake. The treatment milk diet offered to the calves had an F:P of 1.3:1 in $\mathrm{M}$, and 1.1:1 in MP and MPA. Milk was offered at $10.4 \%$ of birth weight until weaning, and total milk used was greater in $M$ compared with MP and MPA, whereas no difference between MP and MPA was observed (Table 6). The daily DM, ME, protein, and starch intakes were greater for calves fed MP and MPA compared with M. The daily mean intake of starter and straw did not differ among the 3 groups (Table 6). The total amount of calf starter consumed during the milk-feeding period was lower for calves receiving MPA compared with calves receiving $\mathrm{M}$, but not compared with those receiving MP. No difference in starter feed intake was observed between calves offered M or MP. The feed conversion efficiency (FCE; kilograms of dry feed intake per kilograms of BW gain) was better in MPA, which had a lower starter and straw DMI requirement per kilogram of BW gain compared with MP and M. 
Table 4. Mean $( \pm \mathrm{SEM})$ plasma proteins, BW, weight gain, number of days to weaning, fecal score, and days medicated in dairy heifers reared on $4 \mathrm{~L}$ /animal per day of whole milk $(\mathrm{M}), 4 \mathrm{~L} /$ animal per day of milk with plant carbohydrates (MP), or $4 \mathrm{~L} /$ animal per day of milk with plant carbohydrates with amino acids (MPA)

\begin{tabular}{|c|c|c|c|c|c|}
\hline \multirow[b]{2}{*}{ Item } & \multicolumn{3}{|c|}{ Milk diet } & \multirow[b]{2}{*}{ SEM } & \multirow[b]{2}{*}{$P$-value } \\
\hline & M & MP & MPA & & \\
\hline Birth weight, kg & 38.3 & 39.1 & 38.5 & 0.910 & 0.81 \\
\hline Serum protein, ${ }^{\circ} \mathrm{g} / \mathrm{L}$ & 6.64 & 6.46 & 6.50 & 0.610 & 0.37 \\
\hline Serum $\mathrm{IgG},{ }^{1} \mathrm{mg} / \mathrm{L}$ & 2,665 & 2,556 & 2,550 & 89.1 & 0.37 \\
\hline Fecal score & 2.51 & 2.55 & 2.45 & 0.590 & 0.64 \\
\hline Medication applied, d & 0.09 & 0.08 & 0.08 & 0.120 & 0.98 \\
\hline $\mathrm{BW}$ at $18 \mathrm{~d}, \mathrm{~kg}$ & 45.4 & 45.3 & 45.4 & 0.86 & 0.64 \\
\hline Weight at weaning, $\mathrm{kg}$ & 92.8 & 91.2 & 92.2 & 0.59 & 0.42 \\
\hline Time to weaning, $d$ & $82.9^{\mathrm{a}}$ & $77.7^{\mathrm{ab}}$ & $74.5^{\mathrm{b}}$ & 1.85 & 0.01 \\
\hline
\end{tabular}

a,b Means in rows followed by differing superscript letters differ significantly $(P<0.05)$.

${ }^{1}$ Blood samples were taken between 48 and $60 \mathrm{~h}$ after birth for IgG and protein analysis.

${ }^{2}$ Fecal scores were rated as follows: $1=$ soft and watery, $2=$ soft, $3=$ pudding-like, $4=$ firm and dry.

\section{Mating, Calving, and Milk Production}

At mating, no difference was observed in BW of heifers fed M, MP, or MPA as calves (Figure 1). At parturition, no differences were observed in hip height, width, BW, BCS, and days to first estrus between the 3 treatment groups (Table 7). The number of inseminations and the pregnancy rate were similar between

Table 5. Mean $( \pm$ SEM) BW, growth rate, and height of dairy heifers reared (19 d to weaning) on $4 \mathrm{~L} /$ animal per day of whole milk (M), or $4 \mathrm{~L} /$ animal per day of milk with plant carbohydrates (MP), or $4 \mathrm{~L} /$ animal per day of milk with plant carbohydrates with amino acids (MPA)

\begin{tabular}{|c|c|c|c|c|c|}
\hline \multirow[b]{2}{*}{ Item } & \multicolumn{3}{|c|}{ Milk diet } & \multirow[b]{2}{*}{ SEM } & \multirow[b]{2}{*}{$P$-value } \\
\hline & M & $\mathrm{MP}$ & MPA & & \\
\hline \multicolumn{6}{|l|}{ BW gain, g/d } \\
\hline 1 to $18 \mathrm{~d}$ & 394 & 344 & 383 & 0.194 & 0.55 \\
\hline 19 to $39 \mathrm{~d}$ & 696 & 758 & 803 & 0.395 & 0.15 \\
\hline 40 to $60 \mathrm{~d}$ & 703 & 749 & 840 & 0.417 & 0.07 \\
\hline 61 to $82 \mathrm{~d}$ & $902^{\mathrm{b}}$ & $988^{\mathrm{ab}}$ & $1,071^{\mathrm{a}}$ & 0.424 & 0.03 \\
\hline Mean gain, ${ }^{1} \mathrm{~g} / \mathrm{d}$ & $765^{\mathrm{b}}$ & $815^{\mathrm{ab}}$ & $876^{\mathrm{a}}$ & 0.25 & 0.01 \\
\hline \multicolumn{6}{|l|}{ Hip height, $\mathrm{cm}$} \\
\hline 1 to $18 \mathrm{~d}$ & 80.0 & 80.0 & 79.8 & 3.95 & 0.64 \\
\hline 19 to $39 \mathrm{~d}$ & 83.4 & 83.0 & 82.7 & 4.11 & 0.52 \\
\hline 40 to $60 \mathrm{~d}$ & 87.5 & 87.8 & 87.8 & 7.32 & 0.77 \\
\hline 61 to $82 \mathrm{~d}$ & 91.3 & 91.5 & 91.1 & 3.82 & 0.73 \\
\hline Mean gain, ${ }^{1} \mathrm{~cm} / \mathrm{d}$ & 0.12 & 0.14 & 0.15 & 0.013 & 0.48 \\
\hline \multicolumn{6}{|l|}{ Hip width, cm } \\
\hline 1 to $18 \mathrm{~d}$ & 18.1 & 18.0 & 18.0 & 1.21 & 0.93 \\
\hline 19 to $39 \mathrm{~d}$ & 19.3 & 19.3 & 19.5 & 1.38 & 0.99 \\
\hline 40 to $60 \mathrm{~d}$ & $20.7^{\mathrm{b}}$ & $20.9^{\mathrm{a}, \mathrm{b}}$ & $21.2^{\mathrm{a}}$ & 1.25 & 0.01 \\
\hline 61 to $82 \mathrm{~d}$ & 22.4 & 22.7 & 22.8 & 1.29 & 0.10 \\
\hline Mean gain, ${ }^{1} \mathrm{~cm} / \mathrm{d}$ & $0.05^{\mathrm{b}}$ & $0.06^{\mathrm{ab}}$ & $0.06^{\mathrm{a}}$ & 0.017 & 0.01 \\
\hline \multicolumn{6}{|l|}{ Heart girth, cm } \\
\hline 1 to $18 \mathrm{~d}$ & 87.3 & 87.0 & 87.0 & 3.21 & 0.93 \\
\hline 19 to $39 \mathrm{~d}$ & 89.3 & 89.3 & 89.5 & 3.38 & 0.99 \\
\hline 40 to $60 \mathrm{~d}$ & $90.7^{\mathrm{b}}$ & $91.9^{\mathrm{ab}}$ & $92.2^{\mathrm{a}}$ & 3.25 & 0.01 \\
\hline 61 to $82 \mathrm{~d}$ & $91.4^{\mathrm{b}}$ & $92.7^{\mathrm{ab}}$ & $93.8^{\mathrm{a}}$ & 3.29 & 0.05 \\
\hline Mean gain, ${ }^{1} \mathrm{~cm} / \mathrm{d}$ & $0.01^{\mathrm{b}}$ & $0.01^{\mathrm{b}}$ & $0.02^{\mathrm{a}}$ & 0.001 & 0.02 \\
\hline \multicolumn{6}{|l|}{ Last rib girth, cm } \\
\hline 1 to $18 \mathrm{~d}$ & 93.1 & 93.0 & 93.0 & 3.51 & 0.93 \\
\hline 19 to $39 \mathrm{~d}$ & 95.3 & 95.3 & 95.5 & 3.78 & 0.99 \\
\hline 40 to $60 \mathrm{~d}$ & 97.0 & 98.1 & 99.9 & 3.71 & 0.05 \\
\hline 61 to $82 \mathrm{~d}$ & $98.7^{\mathrm{b}}$ & $108.9^{\mathrm{ab}}$ & $109.2^{\mathrm{a}}$ & 4.05 & 0.01 \\
\hline Mean gain, ${ }^{1} \mathrm{~cm} / \mathrm{d}$ & $0.05^{\mathrm{b}}$ & $0.23^{\mathrm{a}}$ & $0.24^{\mathrm{a}}$ & 0.011 & 0.01 \\
\hline
\end{tabular}

$\overline{a, b}$ Means in rows followed by differing superscript letters differ significantly $(P<0.05)$.

${ }^{1}$ Mean of the period when differing experimental diets were offered $(19 \mathrm{~d}$ to weaning). 
Table 6. Mean total levels $( \pm$ SEM) of differing feeds consumed ( $\mathrm{kg}$ of DM/animal per day) and feed conversion efficiency (FCE) by dairy heifers reared on $4 \mathrm{~L} /$ animal per day of whole milk (M), or $4 \mathrm{~L} /$ animal per day of milk with plant carbohydrates (MP), or $4 \mathrm{~L} /$ animal per day of milk with plant carbohydrates with amino acids (MPA)

\begin{tabular}{|c|c|c|c|c|c|}
\hline \multirow[b]{2}{*}{ Item } & \multicolumn{3}{|c|}{ Milk diet } & \multirow[b]{2}{*}{ SEM } & \multirow[b]{2}{*}{$P$-value } \\
\hline & M & MP & MPA & & \\
\hline Milk intake, L/animal & 4 & 4 & 4 & - & - \\
\hline Total milk used, L & $331.6^{\mathrm{a}}$ & $310.8^{\mathrm{b}}$ & $298^{\mathrm{b}}$ & 7.4 & 0.04 \\
\hline Treatment diet intake, ${ }^{1} \mathrm{~kg}$ of $\mathrm{DM} /$ animal per day & $0.51^{\mathrm{b}}$ & $0.69^{\mathrm{a}}$ & $0.69^{\mathrm{a}}$ & 0.005 & 0.04 \\
\hline Starter intake, $\mathrm{kg}$ of DM/animal per day & $0.72^{\mathrm{a}}$ & $0.68^{\mathrm{a}}$ & $0.66^{\mathrm{b}}$ & 0.016 & 0.02 \\
\hline Straw intake, $\mathrm{kg}$ of $\mathrm{DM} /$ animal per day & 0.27 & 0.28 & 0.28 & 0.012 & 0.73 \\
\hline Total DMI, $\mathrm{kg}$ /animal per day & $1.50^{\mathrm{b}}$ & $1.65^{\mathrm{a}}$ & $1.63^{\mathrm{a}}$ & 0.015 & $<0.01$ \\
\hline $\mathrm{FCE},{ }^{2} \mathrm{~kg}$ of DMI $/ \mathrm{kg}$ of $\mathrm{BW}$ gain per day & $0.10^{\mathrm{a}}$ & $0.96^{\mathrm{a}}$ & $0.93^{\mathrm{b}}$ & 0.013 & 0.02 \\
\hline Energy, MJ of ME/animal per day & 19.6 & 19.4 & 19.0 & 0.18 & 0.11 \\
\hline $\mathrm{CP}, \mathrm{g} /$ animal per day & 164.7 & 165.6 & 165.0 & 0.39 & 0.29 \\
\hline
\end{tabular}

${ }_{\mathrm{a}, \mathrm{b}}$ Means in rows followed by differing superscript letters differ significantly $(P<0.05)$.

${ }^{1}$ The MP or MPA added to the milk diet

${ }^{2}$ Starter and straw diet.

groups, although the relatively small number of animals used in this study precludes substantial inference being made from this reproduction data.

The mean daily FCM yield was greater in heifers fed either the MP or MPA diet compared with M (Table 7). In addition, milk fat concentration, total milk fat, and total milk protein yields were greater in MP or MPA compared with M. None of the diets assessed in this study had an effect on milk protein concentration or SCC.

\section{DISCUSSION}

In the United States, dairy farmers generally use MR in feeding programs for heifer calves following a period of colostrum feeding (USDA, 2007), whereas farmers

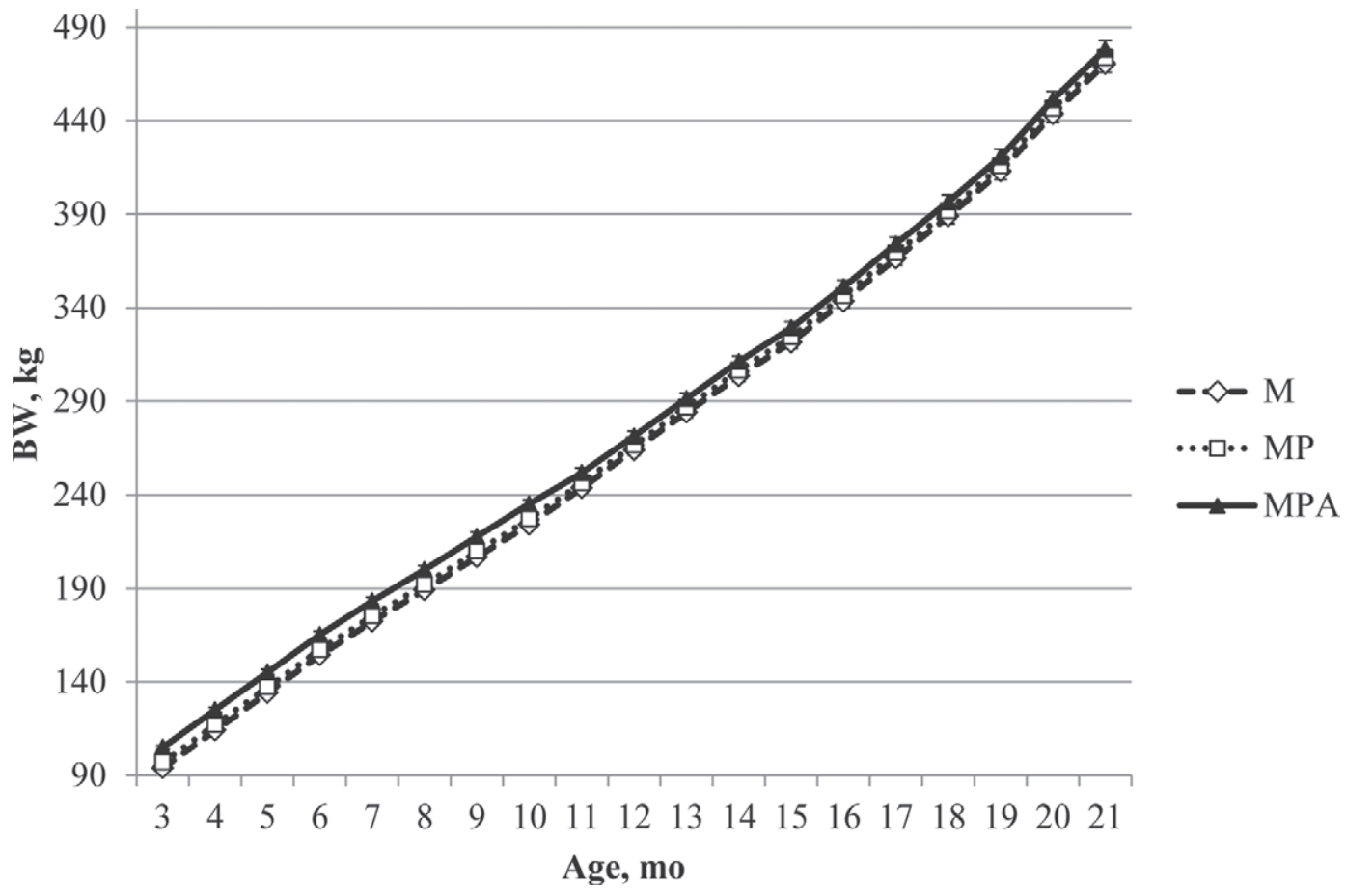

Figure 1. Body weight of heifers between 3 and 21 mo of age (reared as calves from $19 \mathrm{~d}$ to weaning at approximately $90 \mathrm{~kg}$ ) on $4 \mathrm{~L} / \mathrm{animal}$ per day of whole milk (M), or $4 \mathrm{~L} /$ animal per day of milk with plant carbohydrates (MP), or $4 \mathrm{~L} /$ animal per day of milk with plant carbohydrates with amino acids (MPA). 
Table 7. Mean number of heifers calved, height, BW, and pregnancy rate of first lactation dairy heifers reared on $4 \mathrm{~L} /$ animal per day of whole milk $(\mathrm{M})$, or $4 \mathrm{~L} /$ animal per day of milk with plant carbohydrates (MP), or 4 L/animal per day of milk with plant carbohydrates with amino acids (MPA)

\begin{tabular}{|c|c|c|c|c|c|}
\hline \multirow[b]{2}{*}{ Item } & \multicolumn{3}{|c|}{ Milk diet } & \multirow[b]{2}{*}{ SEM } & \multirow[b]{2}{*}{$P$-value } \\
\hline & M & MP & MPA & & \\
\hline \multicolumn{6}{|l|}{ At first parturition } \\
\hline Animals calved, ${ }^{1} \%$ & 95 & 100 & 100 & - & - \\
\hline Hip height, cm & 138 & 137 & 137 & 0.97 & 0.84 \\
\hline Hip width, cm & 49.0 & 49.0 & 49.1 & 0.45 & 0.69 \\
\hline $\mathrm{BW}, \mathrm{kg}$ & 480.4 & 483.1 & 485.6 & 40.10 & 0.70 \\
\hline Body condition $^{2}$ & 5.54 & 5.50 & 5.49 & 0.91 & 0.69 \\
\hline \multicolumn{6}{|l|}{ First lactation performance } \\
\hline Corrected yield,$^{3} \mathrm{~kg} / \mathrm{d}$ & $16.8^{\mathrm{b}}$ & $18.8^{\mathrm{a}}$ & $18.7^{\mathrm{a}}$ & 0.23 & 0.01 \\
\hline Milk fat, $\mathrm{g} / \mathrm{kg}$ & $47.7^{\mathrm{b}}$ & $49.9^{\mathrm{a}}$ & $49.5^{\mathrm{a}}$ & 0.53 & 0.01 \\
\hline Milk protein, $\mathrm{g} / \mathrm{kg}$ & 35.2 & 35.1 & 35.4 & 0.27 & 0.65 \\
\hline Total fat, $\mathrm{kg}$ & $206^{\mathrm{b}}$ & $228^{\mathrm{a}}$ & $223^{\mathrm{a}}$ & 5.0 & 0.01 \\
\hline Total protein, $\mathrm{kg}$ & $149^{\mathrm{b}}$ & $159^{\mathrm{a}}$ & $158^{\mathrm{a}}$ & 2.8 & 0.04 \\
\hline $\mathrm{SCC}$, cells $/ \mathrm{mL}$ & 57.0 & 72.5 & 78.0 & 22.0 & 0.19 \\
\hline DIM & 279 & 278 & 281 & 9.1 & 0.97 \\
\hline Hip height, cm & 158 & 159 & 160 & 0.6 & 0.76 \\
\hline Hip width, cm & 52.0 & 53.0 & 53.0 & 0.25 & 0.62 \\
\hline $\mathrm{BW}, \mathrm{kg}$ & 520.4 & 523.1 & 526.6 & 30.10 & 0.60 \\
\hline Body condition $^{2}$ & 5.34 & 5.30 & 5.36 & 0.70 & 0.69 \\
\hline \multicolumn{6}{|l|}{ Reproductive performance } \\
\hline Period to first estrus, $\mathrm{d}$ & 38.3 & 36.6 & 39.1 & 0.67 & 0.83 \\
\hline Inseminations per conception ${ }^{4}$ & 1.4 & 1.2 & 1.3 & 0.47 & 0.81 \\
\hline Fertility rate, ${ }^{5} \%$ & 95 & 97 & 97 & - & - \\
\hline \multicolumn{6}{|c|}{ a,b Means in rows followed by differing superscript letters differ significantly $(P<0.05)$. } \\
\hline \\
\hline \multicolumn{6}{|c|}{${ }^{2}$ On a 0 - to 10 -point scale; 0 being extremely low body fat reserves and 10 being obese. } \\
\hline \multicolumn{6}{|c|}{${ }^{3}$ Fat corrected to $40 \mathrm{~g} / \mathrm{kg}$. } \\
\hline \multicolumn{6}{|c|}{${ }^{4}$ Artificial inseminations used per animal. } \\
\hline
\end{tabular}

in New Zealand continue to feed colostrum until the substantial stored reserves are exhausted, followed by WM. The advent of intensified feeding programs using MR formulations with a similar composition to WM has prompted an evaluation of costs and benefits in comparison to more traditional MR (Brown et al., 2005 a,b; Cowles et al., 2006). More recent studies have focused on the long-term effects of greater levels of traditional MR (Davis Rincker et al., 2011; Khan et al., 2011; Soberon et al., 2012) or WM feeding programs.

Previous studies have indicated that to maximize milk yield, BW gains of around $700 \mathrm{~g} / \mathrm{d}$ (up to $900 \mathrm{~g} / \mathrm{d}$ ) are optimal (Foldager and Sejrsen, 1987). In the current study, increasing the nutrient concentration and reducing the $\mathrm{F}: \mathrm{P}$ ratio of $\mathrm{WM}$ from $1.3: 1$ to $1.1: 1$ by the addition of plant carbohydrates as a nonfat energy source, with or without the addition of AA, increased the growth rates of calves over the WM-feeding period from 680 to 715 and $780 \mathrm{~g} / \mathrm{d}$ in the M, MP, and MPA diets, respectively. In addition, the MPA calves had greater mean hip width and heart and last rib girth gains compared with calves offered $\mathrm{M}$, and this tended to be greater between 40 and $61 \mathrm{~d}$ and was greatest be- tween 61 and $82 \mathrm{~d}$. These results are similar to previous studies (Bach, 2012) in which increased weight gains are accompanied by increased height. In the current study, increases in heart girth could have been due to greater rumen fill, but this seems unlikely considering that straw and concentrate intake were no different between treatment groups.

In the first lactation, the daily milk yield of calves offered MP or MPA was greater, with an FCM yield 1.9 to $2.0 \mathrm{~kg} / \mathrm{d}$ greater than the $\mathrm{M}$ group. These results are similar to those reported in studies comparing intensive MR (increased protein, reduced fat) with a conventional MR program, where, across trials, an increase in milk yield was observed from calves on the intensive MR program (Khan et al., 2011; Bach, 2012; Soberon et al., 2012). However, in the current study, milk yields were above those anticipated (Soberon et al., 2012). In the study by Soberon et al. (2012), feeding milk longer (49.3-63.6 d) was associated with increased milk yield, which was closest to the milk-feeding period in MP and MPA; the longest milk-feeding period was in calves fed M. It is common practice to wean according to BW in New Zealand, and, in the current study, the differing 
periods to weaning among treatments resulted in different diets being fed at differing ages and physiological stages. This may have been sufficiently long, in diet $\mathrm{M}$, to be associated with impaired mammary development (Sejrsen and Purup. 1997; Brown et al., 2005 a,b; Meyer et al., 2006) and warrants further research.

In a recent study using WM diets, Moallem et al. (2010) observed first-lactation milk yields were $10.3 \%$ higher in heifers fed ad libitum, which they associated with biologically active factors not found in MR. Milk and colostrum have a significant developmental function at the tissue or organ level (Nusser and Frawley, 1997; Bagnell et al., 2005), resulting in the epigenetic development of specific tissues or physiological functions (Bartol et al., 2008). This suggests that not only the length of the feeding period, the nutrient intake, and source, but a combination of these along with biologically active factors in WM milk may be responsible for the enhanced milk yield in this study.

In the current study, calves offered MP and MPA had 7.4 and $11.4 \mathrm{~kg}$ reductions in total starter intake, respectively, compared with calves in the $\mathrm{M}$ treatment group. These were lower than reductions found in studies in which calves that received high levels of MR had the lowest total starter intake up to weaning, consuming $19.0 \mathrm{~kg}$ compared with an average of $31.3 \mathrm{~kg}$ for more conventional feeding programs (Raeth-Knight et al., 2009). Other studies have shown a 36 to $55 \%$ reduction in starter intake during the preweaning to early postweaning period for calves offered an intensive rather than a conventional MR program (Jasper and Weary, 2002; Cowles et al., 2006). In general, reduced starter intake levels are associated with increased daily liquid consumption of milk or MR (Jasper and Weary, 2002; Margerison and Downey, 2005; Quigley et al., 2006). However, in the current study, the daily WM feeding level was held constant, and the difference in total starter feed intake was due to the addition of plant carbohydrates and proteins, $\mathrm{AA}$, and a reduction in the number of days required for calves in the MP and MPA groups to achieve the target weaning weight. In fact, the mean daily starter intake was not different between treatments, indicating that the addition of plant carbohydrates and AA to milk in this study had a minimal effect on daily calf starter intake. The amount of feeds (starter and straw) required for BW gain were lower in MPA compared with M and MP. This could be the result of a more developed ability to digest and use cereal carbohydrates due to a greater rate of the development of exocrine pancreatic function, which was been found to be greater in mammals fed milk diets containing plant carbohydrates (Zoppi et al., 1972). Bascom et al. (2007) found that calves fed WM diets had the highest BW gains and FCE compared with calves offered MR. The greater FCE in WM diets in this study could be due to a more optimal supply of $\mathrm{AA}$, as FCE was greatest in calves offered MPA and did not differ between calves fed M and MP. This is in keeping with previous research, showing greater growth rates in calves fed $\mathrm{WM}$ and $\mathrm{MR}$ with additional $\mathrm{AA}$ (Hill et al., 2008).

Increasing the energy and protein intake of preweaned calves could result in an earlier age of calving and influence dairy costs. Even small changes in calving age may have a significant effect on a heifer replacement program, with one study reporting that a 1 -mo reduction in calving age decreased costs by $4.3 \%$ (Tozer and Heinrichs, 2001). However, it is important that any reduction in calving age should not negatively affect reproduction, lactation, or survivability (Ettema and Santos, 2004). In New Zealand, calving patterns of dairy cattle are strongly seasonal, which would limit the opportunity for differences in the calving age of heifers in any of the dietary feeding groups, even with the limited number of animals used in this study. In studies elsewhere, where calving dates are less seasonal, calves offered a high-energy or high-protein MR and calves offered milk diets at greater levels during the preweaning stage tended to conceive and give birth at a younger age compared with calves offered more conventional MR programs (Raeth-Knight et al., 2009; Davis Rincker et al., 2011).

Previous publications have indicated that calves that gained more BW during the preweaning period had increased mammary growth (Brown et al., 2005 a,b), and calves consuming WM gained BW faster and produced more milk in their first lactation than those reared on MR (Davis Rincker et al., 2011; Khan et al., 2011; Soberon et al., 2012). In a recent study, differences in preweaning BW gain accounted for $22 \%$ of the variation in first lactation milk yield, indicating that increased growth rates during the milk-feeding period can have a positive effect on subsequent milk yield (Soberon et al., 2012). In support of this observation, data from the current study indicates that calves offered MP or MPA during the preweaning period produced a greater average first lactation milk yield compared with animals reared on M. However, in other studies using intensive MR programs and conventional MR programs, differences in yield have been less pronounced (Raeth-Knight et al., 2009; Davis Rincker et al., 2011; Soberon et al., 2012), which may in part be due to differences in the length of time to weaning in these studies. In contrast, Morrison et al. (2009) found no difference in first lactation performance between heifers offered an intensive or moderate MR program; however, because only results for the first 60 DIM were reported, longer lactation studies would appear to be required, along with consid- 
eration of milk component payment systems, which are an important factor in dairy farm economics.

\section{CONCLUSIONS}

In this study, increasing energy, protein (low amylose plant carbohydrates), and AA (Lys, Met, Cys, and Thr) concentrations of WM, restricted to $10.4 \%$ of birth weight, increased calf BW gain and FCE during the milk-feeding period. Hip width, heart girth, and last rib girth gain rates were also increased. The average milk fat and protein yield, along with total FCM yield, was found to be greater in calves raised on the carbohydrate- and AA-supplemented milk diet, most likely the result of the improved growth and development before weaning. No effects of treatments on calving age or mature weight at calving were observed. The effect of calf nutrition on animal growth and lactation is a key factor in increasing the environmental and financial sustainability of dairy production systems. As reported here, supplementing milk diets with carbohydrates, proteins, and selected AA appears to be an effective means of improving calf nutrition and obtaining increases in calf growth and first lactation milk yield.

\section{ACKNOWLEDGMENTS}

The authors thank Sally Mitchell (Massey University) for editorial assistance with the preparation and formatting of this manuscript.

\section{REFERENCES}

AOAC International. 2000. Official Methods of Analysis. 17th ed. AOAC International, Arlington, VA.

Bach, A. 2012. Optimizing performance of the offspring: Nourishing and managing the dam and post-natal calf for optimal lactation, reproduction, and immunity. J. Anim. Sci. 90:1835-1845.

Bagnell, C. A., W. Yan, A. A. Wiley, and F. F. Bartol. 2005. Effects of relaxin on neonatal porcine uterine growth and development. Ann. N. Y. Acad. Sci. 1041:248-255.

Bartlett, K. S., F. K. McKeith, M. J. VandeHaar, G. E. Dahl, and J. K. Drackley. 2006. Growth and body composition of dairy calves fed milk replacers containing different amounts of protein at two feeding rates. J. Anim. Sci. 84:1454-1467.

Bartol, F. F., A. A. Wiley, and C. A. Bagnell. 2008. Epigenetic programming of porcine endometrial function and the lactocrine hypothesis. Reprod. Domest. Anim. 43:273-279.

Bascom, S. A., R. E. James, M. L. McGilliard, and M. E. Van Amburgh. 2007. Influence of dietary fat and protein on body composition of Jersey bull calves. J. Dairy Sci. 90:5600-5609.

Brown, E. G., M. J. VandeHaar, K. M. Daniels, J. S. Liesman, L. T. Chapin, and J. W. Forrest. 2005a. Effect of increasing energy and protein intake on mammary development in heifer calves. J. Dairy Sci. 88:595-603.

Brown, E. G., M. J. VandeHaar, K. M. Daniels, J. S. Liesman, L. T. Chapin, and D. H. Keisler. 2005b. Effect of increasing energy and protein intake on body growth and carcass composition of heifer calves. J. Dairy Sci. 88:585-594.
Cowles, K. E., R. A. White, N. L. Whitehouse, and P. S. Erickson. 2006. Growth characteristics of calves fed an intensified milk replacer regimen with additional lactoferrin. J. Dairy Sci. 89:48354845.

Dairy NZ. 2012. New Zealand Dairy Statistics. Livestock Improvement Company and DairyNZ Ltd., Publications, Hamilton, New Zealand.

Davis Rincker, L. E., M. J. VandeHaar, C. A. Wolf, J. S. Liesman, L. T. Chapin, and M. S. Weber Nielsen. 2011. Effect of intensified feeding of heifer calves on growth, pubertal age, calving age, milk yield, and economics. J. Dairy Sci. 94:3554-3567.

Diaz, M. C., M. E. Van Amburgh, J. M. Smith, J. M. Kelsey, and E. L. Hutten. 2001. Composition of growth of Holstein calves fed milk replacer from birth to 105-kilogram body weight. J. Dairy Sci. 84:830-842.

Ettema, J. F., and J. E. P. Santos. 2004. Impact of age at calving on lactation, reproduction, health and income in first-parity Holsteins on commercial farms. J. Dairy Sci. 87:2730-2742.

Foldager, J., and K. Sejrsen. 1987. Mammary gland development and milk production in dairy cows in relation to feeding and hormone manipulation during rearing. Pages 102-115 in Research in Cattle Production: Danish Status and Perspectives. B. B. Andersen, E. Andersen, B. Jensen, P. H. Petersen, and V. Ostergard, ed. Danske Landhuusholdingsselskab, Odensk, Denmark.

Guilloteau, P., R. Zabielski, and J. W. Blum. 2009. Gastrointestinal tract and digestion in the young ruminant: Ontogenesis, adaptations, consequences and manipulations. J. Physiol. Pharmacol. 60(Suppl. 3):37-46.

Hill, T. M., J. M. Aldrich, R. L. Schlotterbeck, and H. G. Bateman II.. 2007. Amino acids, fatty acids, and fat sources for calf milk replacers. Prof. Anim. Sci. 23:401-408.

Hill, T. M., H. G. Bateman, J. M. Aldrich, and R. L. Schlotterbeck. 2010. Effect of milk replacer program on digestion of nutrients in dairy calves. J. Dairy Sci. 93:1105-1115.

Hill, T. M., H. G. Bateman II, J. M. Aldrich, R. L. Schlotterbeck, and K. G. Tanan. 2008. Optimal concentration of lysine, methionine, and threonine in milk replacers for calves less than five weeks of age. J. Dairy Sci. 91:2433-2442.

Huber, J. T., S. Natrajan, and C. E. Polan. 1968. Varying levels of starch in calf milk replacers. J. Dairy Sci. 51:1081-1084.

Jasper, J., and D. M. Weary. 2002. Effects of ad libitum milk intake on dairy calves. J. Dairy Sci. 85:3054-3058.

Khan, M. A., H. J. Lee, W. S. Lee, H. S. Kim, K. S. Ki, T. Y. Hur, G. H. Suh, S. J. Kang, and Y. J. Choi. 2007a. Structural growth rumen development, metabolic and immune response of Holstein male calves fed milk through step-down and conventional methods. J. Dairy Sci. 90:3376-3387.

Khan, M. A., H. J. Lee, W. S. Lee, H. S. Kim, S. B. Kim, K. S. Ki, J. K. Ha, H. G. Lee, and Y. J. Choi. 2007b. Pre- and post-weaning performance of Holstein female calves fed milk through step-down and conventional methods. J. Dairy Sci. 90:876-885.

Khan, M. A., D. M. Weary, and M. A. G. von Keyserlingk. 2011. Invited review: Effects of milk ration on solid feed intake, weaning, and performance in dairy heifers. J. Dairy Sci. 94:1071-1081.

Margerison, J. K., and N. Downey. 2005. Guidelines for optimal dairy heifer rearing and herd performance. Pages 307-338 in Calf and Heifer Rearing: Principles of Rearing the Modern Dairy Heifer from Calf to Calving. P. C. Garnsworthy, ed. Nottingham University Press, Nottingham, UK.

Meyer, M. J., A. V. Capuco, D. A. Ross, L. M. Lintault, and M. E. Van Amburgh. 2006. Developmental and nutritional regulation of the prepubertal heifer mammary gland: I. Parenchyma and fat pad mass and composition. J. Dairy Sci. 89:4289-4297.

Moallem, U., D. Werner, H. Lehrer, M. Zachut, L. Livshitz, S. Yakoby, and A. Shamay. 2010. Long-term effects of ad libitum whole milk prior to weaning and prepubertal protein supplementation on skeletal growth rate and first-lactation milk production. J. Dairy Sci. 93:2639-2650

Morrison, S. J., H. C. F. Wicks, R. J. Fallon, J. Twigge, L. E. R. Dawson, A. R. G. Wylie, and A. F. Carson. 2009. Effects of feeding 
level and protein content of milk replacer on the performance of dairy herd replacements. Animal 3:1570-1579.

NRC. 2001. Nutrient Requirements of Dairy Cattle. 7th rev. ed. Natl. Acad. Press, Washington, DC.

Nusser, K. D., and S. Frawley. 1997. Depriving neonatal rats of milk from early lactation has long-term consequences on mammotrope development. Endocrine 7:319-323.

Quigley, J. D., T. A. Wolfe, and T. H. Elsasser. 2006. Effects of additional milk replacer feeding on calf health, growth, and selected blood metabolites in calves. J. Dairy Sci. 89:207-216.

Raeth-Knight, M., H. Chester-Jones, S. Hayes, J. Linn, R. Larson, and D. Ziegler. 2009. Impact of conventional or intensive milk replacer programs on Holstein heifer performance through six months of age and during first lactation. J. Dairy Sci. 92:799-809.

SAS Institute. 2004. SAS/STAT User's Guide. Version 9. SAS Institute Inc., Cary, NC.

Sejrsen, K., and S. Purup. 1997. Influence of prepubertal feeding level on milk yield potential of dairy heifers: A review. J. Anim. Sci. 75:828-835.

Soberon, F., E. Raffrenato, R. W. Everett, and M. E. Van Amburgh 2012. Preweaning milk replacer intake and effects on long-term productivity of dairy calves. J. Dairy Sci. 95:783-793.

Suarez-Mena, F. X., T. M. Hill, A. J. Heinrichs, H. G. Bateman II, J. M. Aldrich, and R. L. Schlotterbeck. 2011. Effects of including corn distillers dried grains with solubles in dairy calf feeds. J. Dairy Sci. 94:3037-3044.
Terré, M., M. Devant, and A. Bach. 2007. Effect of level of milk replacer fed to Holstein calves on performance during the pre-weaning period and starter digestibility at weaning. Livest. Sci. 110:82-88.

Tikofsky, J. N., M. E. Van Amburgh, and D. A. Ross. 2001. Effect of varying carbohydrate and fat content of milk replacer on body composition of calves. J. Anim. Sci. 79:2260-2267.

Toullec, R. 1989. Veal calves. Pages 109-151 in Ruminant NutritionRecommended Allowances and Feed Tables. R. Jarrige, ed. INRA, John Libby, London, UK.

Tozer, P. R., and A. J. Heinrichs. 2001. What affects the costs of raising replacement dairy heifers: A multiple-component analysis. J. Dairy Sci. 84:1836-1844.

USDA. 2007. Reference of Dairy Health and Management in the United States, Part I. National Animal Health Monitoring System. USDA, Fort Collins, CO.

Van AmburghM. E. 2012. Ruminant nutrition symposium: Update on nutrient requirements for ruminants. J. Dairy Sci. 95(Suppl. 2):739. (Abstr.)

Van Soest, P. J., J. B. Robertson, and B. A. Lewis. 1991. Methods for dietary fiber, neutral detergent fiber, and nonstarch polysaccharides in relation to animal nutrition. J. Dairy Sci. 74:3583-3597.

Zoppi, G., G. Andreotti, F. Pajno-Ferrara, D. M. Njai, and D. Garburro. 1972. Exocrine pancreas function in premature and full term neonates. Pediatr. Res. 6:880-886. 